\title{
EKSISTENSI HUKUM ISLAM DALAM UNDANG-UNDANG RI NOMOR 36 TAHUN 2009 TENTANG KESEHATAN DI INDONESIA
}

\author{
Zul Anwar Ajim Harahap \\ (Lecturer of of Shariah and Law Sciences Faculty at IAIN Padangsidimpuan) \\ Email: anwarharahap@yahoo.com
}

\begin{abstract}
This research begins from the reality of the existence of the provisions of the legislation Health which, according to the analysis of the authors has a dimension of Islamic law, so this research motivated the problem of the existence of Islamic law into national law and how Islamic law in the Law of health. The methodology was use a qualitative research, so that the analysis was use interpretative analysis, and comparative and inductive analysis. Results found is that Islamic law has existed in the legislation of health, seen from the passages that are similar to the context of Islamic law.
\end{abstract}

Key Words: Existence, Islamic Law, Health Law

\begin{abstract}
Abstrak
Penelitian ini berawal dari kenyataan tentang adanya ketentuan dalam Undang-undang kesehatan yang menurut analisa penulis memiliki dimensi hukum Islam, sehingga penelitian ini dilatarbelakangi adanya masalah eksistensi hukum Islam dalam hukum nasional dan bagaiman hukum islam dalam Undang-undang kesehatan. Metodologi yang digunakan adalah metodologi studi kualitatif, sehingga analisa yang dipakai adalah analisa interpretative, dan komparatif dan analisa induktif. Hasil yang ditemukan adalah bahwa hukum Islam telah eksis dalam Undang-undang kesehatan, terlihat dari adanya pasalpasal yang mirip dengan konteks hukum islam.

Kata Kunci : Eksistensi, Hukum Islam, Undang-undang Kesehatan.
\end{abstract}

\section{PENDAHULUAN}

Dalam perjalanan Kodifikasi Hukum Nasional Indonesia, keberadaan hukum Islam sangat penting, selain sebagai materi bagi penyusunan hukum nasional, hukum Islam juga menjadi inspirator dan dinamisator dalam pengembangan hukum nasional. Hukum Islam sangat dekat dengan sosioantropologis bangsa Indonesia, sehingga kehadirannya dapat dengan mudah diterima oleh masyarakat luas.

Hukum Islam memiliki prospek dan potensi yang sangat besar dalam pembangunan hukum nasional. beberapa contoh hukum Islam yang sudah menjadi hukum nasional antara lain: UU Perkawinan, UU Peradilan Agama, UU Penyelenggaraan Ibadah Haji, UU Pengelolaan Zakat, dan UU Otonomi Khusus Nanggroe Aceh Darussalam serta beberapa undang-undang lain, baik yang secara langsung maupun tidak langsung memuat hukum Islam seperti UU Nomor 10 Tahun 1998 tentang perbankan yang mengakui 
keberadaan Bank Syari'ah dengan prinsip syari'ahnya., atau UU NO. 3 Tahun 2006 tentang Peradilan Agama yang semakin memperluas kewenangannya, dan UU Nomor 21 Tahun 2008 tentang Perbankan Syariah.

Masuknya hukum Islam dalam hukum Nasional seperti yang dikemukakan dalam teori eksistensi di atas, dapat digambarkan dalam produk-produk yang sudah ada. Di antara produk undang-undang dan peraturan yang bernuansa hukum Islam, umumnya memiliki tiga bentuk: Pertama, hukum Islam yang secara formil maupun material menggunakan corak dan pendekatan keislaman; Kedua, hukum Islam dalam proses taqnin diwujudkan sebagai sumber-sumber materi muatan hukum, di mana asas-asas dan pninsipnya menjiwai setiap produk peraturan dan perundang-undangan; Ketiga, hukum Islam yang secara formil dan material ditransformasikan secara persuasive source dan authority source.

Sampai saat ini, kedudukan hukum Islam dalam sistem hukum di Indonesia semakin memperoleh pengakuan yuridis. Pengakuan berlakunya hukum Islam dalam bentuk peraturan dan perundang-undangan yang berimplikasi kepada adanya pranata-pranata sosial, budaya, politik dan hukum. Salah satunya adalah diundangkannya Undang Undang No. 1/1974 tentang Perkawinan.

Abdul Ghani Abdullah mengemukakan bahwa berlakunya hukum Islam di Indonesia telah mendapat tempat konstitusional yang berdasar pada tiga alasan, yaitu: Pertama, alasan filosofis, ajaran Islam rnerupakan pandangan hidup, cita moral dan cita hukum mayoritas muslim di Indonesia, dan mi mempunyai peran penting bagi terciptanya norma fundamental negara Pancasila); Kedua, alasan Sosiologis. Perkembangan sejarah masyarakat Islam Indonesia menunjukan bahwa cita hukum dan kesadaran hukum bersendikan ajaran Islam memiliki tingkat aktualitas yang berkesiambungan; dan Ketiga, alasan Yuridis yang tertuang dalam Pasal 24, 25 dan 29 UUD 1945 memberi tempat bagi keberlakuan hukum Islam secara yuridis formal.

\section{METODOLOGI PENELITIAN}

Penelitian diawali dengan rumusan masalah pokok yang akan diteliti adalah :

1. Bagaimana eksistensi Hukum Islam dalam Hukum Nasional?

2. Bagaimana Hukum Islam dalam Peraturan Perundang-undangan bidang Kesehatan di Indonesia?

Tujuan yang ingin dicapai dalam penelitian ini adalah :

1. Untuk mengetahui eksistensi Hukum Islam dalam Hukum Nasional.

2. Untuk menjelaskan bagaimana Hukum Islam dalam Peraturan Perundang-undangan bidang Kesehatan di Indonesia. 
Dalam rangka mendekatkan pemahaman tentang term-term yang dipakai dalam penelitian ini, berikut ini akan digambarkan istilah-istilah yang dianggap penting dengan maksud agar dapat dipahami dengan benar. Istilah-istilah tersebut adalah :

1. Eksistensi

Eksistensi adalah keberadaan sesuatu pada sesuatu yang lain. Dalam penelitian ini, eksistensi yang dimaksud adalah tempat hukum Islam dalam aturan perundangundangan bidang kesehatan, baik yang bersifat nilai hukum islam, atau hukum Islam secra mandiri yang ada dalam rumusan pasal-pasal perundang-undangan bidang kesehatan tersebut.

Dalam perjalanan Kodifikasi Hukum Nasional Indonesia, keberadaan hukum Islam sangat penting, selain sebagai materi bagi penyusunan hukum nasional, hukum Islam juga menjadi inspirator dan dinamisator dalam pengembangan hukum nasional. Untuk lebih mempertegas keberadaan hukum Islam dalam konstalasi hukum nasional dapat dilihat dari Teori eksistensi tentang adanya hukum Islam di dalam hukum nasional Indonesia. Teori ini mengungkapkan bahwa bentuk eksistensi hukum Islam di dalam hukum nasional lndonesia ialah:

a. Ada dalam arti sebagai bagian integral dari hukum nasional lndonesia.

b. Ada dalam arti kemandirian, kekuatan dan wibawanya diakui adanya oleh hukum nasional dan diberi status sebagai hukum nasional.

c. Ada dalam hukum nasional dalam arti norma hukum Islam (agama) berfungsi sebagai penyaring bahan-bahan hukum nasional lndonesia.

d. Ada dalam arti sebagai bahan utama dan unsur utama hukum nasional Indonesia.

\section{Hukum Islam}

Hukum Pidana Islam merupakan sebagian dari Hukum Islam yang ada, untuk menjelaskan maksud dari Hukum Pidana Islam tersebut terlebih dahulu akan dijelaskan tentang hukum Islam.

Hukum Islam dengan berbagai defenisi harus digambarkan dalam tiga bentuknya, yaitu syariat, figh dan hukum Islam. ${ }^{1}$

Syari'ah secara etimologis dapat diartikan jalan menuju sumber air. Dari pengertian ini, syariah berarti keseluruhan jalan hidup yang digarisksn Allah dan diturunkan kepada nabi Muhammad yang mencakup i'tiqodiyah dan akhlaq. Karena itu, pada awalnya syari'ah identik dengan Dien atau millah. ${ }^{2}$

Akan tetapi dalam perkembangan selanjutnya, syari'ah yang berkaitan dengan i'tiqodiyah dipisahkan menjadi ilmu kalam(tauhid) dan syari'ah yang berhubungan

\footnotetext{
${ }_{1}^{1}$ Abdul Manan, Reformasi Hukum Islam di Indonesia, (Jakarta: Rajawali Press, 2006), hal. 37.

${ }^{2}$ A.Hanafi, Pengantar dan Sejarah Hukum Islam, (Jakarta: Bulan Bintang, 1970), hal. 7
} 
dengan akhlak di bahas dalam ilmu tasawuf. Jadi semula syari'ah mempunyai arti yang luas, yaitu meliputi seluruh ajaran agama baik yang berkaitan dengan akidah (itiqodiyah) maupun berkaitan dengan perbuatan lahir dan sikap batin (akhlaq) manusia.

Syari'at juga didefenisikan oleh Abdul Wahab Khallaf sebagai ketentuan Allah berkaitan perbuatan subyek hukum untuk melakukan suatu perbuatan, memilih atau melakukan sesuatu sebagai syarat, sebab atau penghalang. ${ }^{3}$ Dengan demikian syari'ah merupakan khitab Allah yang berhubungan dengan tindak tanduk manusia di luar akhlaq, sehingga syariah berhubungan dengan hukum-hukum yang bersifat amaliah.

Dari beberapa pengertian diatas dapat ditarik sebuah kesimpulan bahwa syari'ah adalah hukum yang di tetapkan Allah dan rasulnya yang secara jelas terdapat dalam Al-Qur'an dan hadis nabi. Karena itu syari'ah bersifat tetap, tidak berubah dan seharusnya tidak ada perbedaan pendapat, seperti kewajiban sholat, zakat, bebuat adil merupakan syari'ah yang jelas diperintahkan Allah.

Sementara itu menurut Amir Syrifuddin, ada ulama yang mengkhususkan pengertian syari'ah dengan apa yang bersangkutan dengan pengadilan dan pengajuan perkara kepada badan peradilan (Mahkamah). Qatadah, pakar Islam klasik sebagaimana diriwayatkan oleh al-Thabari menggunakan kata syari'ah berkaitan dengan hak, kewajiban, perintah dan larangan, dengan tidak mencaktip akidah dan hikmah yang dikandung oleh agama. Dari berbagai defenisi syari'ah tersebut, menurut Dede Rosyada, defenisi yang dikemukakan oleh Syaltout lebih akomodatif, karena mengganbarkan dan mewakili dua jenis syariah, yaitu ketetapan yang diturunkan oleh Allah dan juga mencakup norma yang dihasilkan oleh ijthad manusia dalam usahanya memahami ketetapan Allah itu. ${ }^{4}$

Hukum Islam merupakan istilah khas Indinesia sebagai terjemahan dari al fqh al Islamy atau al-syari'ah al-Islamiyah yang dalam literatur barat disebut Islamic law sebagaimana dikemukakan oleh Joseph Schacht." "Hukum Islam merupakan rangkaian antara kata. "hukum' dan "Islam" yang berasal dari kosa kata bahasa arab hukum dan Islam, dua kata yang banyak disebut dalam Al-Qur'an tetap juga telah menjadi kosa kata baku dalam bahasa Indonesia. Hukum dalam pengertian yang sudah lazim, adalah kumpulan kaidah dan aturan tingkah laku manusia yang berlaku dan mengikat dalam kehidupan masyarakat yang dibuat oleh pihak berwenang. Sedangkan Islam merupakan nama agama yang di turunkan oleh Allah kepada nabi Muhammad sebagai pedoman hidup manusia agar mencapai kebahagiaan di dunia dan keselamatan

\footnotetext{
${ }^{3}$ Abdul Wahab Khallaf, Ushul Figh, (Beirut: Dar al-Fikr, 1995), hal. 21.

${ }^{4}$ Dede Rosyada, Hukum Islam dan Pranata Sosial, (Jakarta: Raja Grafindo Persada), hal. 4.

${ }^{5}$ joseph Schact, Islamic Law, (The University of Chichago, 1955), hal. 12.
} 
di akhirat.

Manfaat dari penelitian ini adalah : bahwa hasil dari penelitian ini diharapkan menjadi bahan kajian dan pemikiran bagi para ahli hukum Islam.

a. Hasilnya diharapkan dapat memperkaya khasanah keilmuan khususnya dalam bidang Hukum Islam.

b. Juga dapat diharapkan sebagai perluasan wawasan para pemikir Hukum Islam, sehingga dapat menjadi pertimbangan dalam menetapkan hukum yang sesuai dengan perkembangan zaman.

c. Pada tataran praktis, hasil penelitian ini diharapkan dapat memberikan sumbangan pemikiran bagi pembentukan peraturan perundang-undangan dalam bentuk perda dalam upaya pelaksanaan Hukum Islam, memberi sumbangan pemikiran bagi para pembuat kebijakan tentang bagaimana proses pelaksanaan Hukum Islam.

\section{PENDEKATAN DAN METODE PENELITIAN}

1. Jenis Penelitian

Jenis penelitian ini adalah penelitian Kualitatif namun bersifat normative yaitu penelitian terhadap identifikasi hukum. ${ }^{6}$

Penelitian ini mencoba memperkuat teori-teori tentang eksistensi dan fungsi Hukum dalam masyarakat, berikut perubahan-perubahan yang terjadi dalam prosesproses perubahan social. Teori-teori inilah yang kemudian lebih terkenal dengan " the social theories of law " dan seluruh kajiannya di sistemasi kedalam kajian " hukum dan Masyarakat" ( law and society ).

2. Pendekatan Penelitian

Pendekatan penelitian yang dilakukan dalam penelitian ini adalah pendekatan Hukum (Law approach), dengan dikhusukan pada pendekatan filsafat Hukum Islam, yang bercirikan logic, kritis terhadap suatu ketentuan Hukum.

3. Sumber Data

Yang menjadi sumber data dalam penelitian ini ada dua, yaitu sumber data primer dan skunder.

Data Primer diperoleh dari Undang-undang nomor 36 Tahun 2009 tentang Kesehatan, ditambah dengan Kajian tentang Hukum Islam yang relevan dengan judul penelitian tersebut, yaitu antara lain :

a. Al-Qawa'id al-Shugra, Beirut: Dar al-Fikr al-Mu'ashirah, 1996.

b. Qawa'id al-Ahkam fi Masalih al-anam, (Beirut: Libanon Muassasat al-Rayyan, Cet ke 2, 1998 M). 
Data Skunder diperoleh dari karya-karya pakar Hukum Islam dan lainnya yang berkaitan dengan bahasan yang sedang diteliti, misalnya Fatawa-Fatwa MUI karya Prof. Dr. M. Atho Mudzhar, Ensiklopedi Hukum Islam, dan lainnya yang menjadi data pendukung dari kebutuhan penelitian.

Ada beberapa metode yang lazim digunakan dalam penelitian Kualitatif, yaitu metode interpretatif, yaitu metode yang digunakan secara umum dalam kajian hermeneutika. ${ }^{7}$ Metode analisa ini adalah suatu metode yang berusaha menjelaskan dan menelusuri pesan dan pengertian dasar dari sebuah pernyataan. ${ }^{8}$

Kedua, metode Analisa induksi, yaitu menganalisa kasus-kasus yang ada kemudian pemahaman yang ditemukan dirumuskan dalam statemen yang umum.

\section{HASIL PENELITIAN}

Dalam usaha meneliti keberadaan hukum Islam yang ada dalam aturan-aturan kesehatan, terlebih dahulu diungkapkan elemen-elemen hukum Islam yang ada dalam aturan-aturan tentang kesehatan, yaitu Undang-undang kesehatan sejak Kemerdekaan sampai undang-undang yang ada dan berlaku sampai hari ini.

1. UU No. 9/1960.

Undang Undang No. 9 Tahun 1960 Tentang : Pokok - Pokok Kesehatan yang dikeluarkan Tanggal : 15 Oktober 1960 yang berisi VI BAB, 17 Pasal dan berisi tentang : Ketentuan-ketentuan Umum, Tugas-tugas Pemerintah, Alat perlengkapan Pemerintah, Usaha Swasta, yang dalam aturan peralihannya menyebutkan bahwa undang-undang ini dibuat untuk membatalkan uu produk Belanda, het Reglement op de Dienst dervoksgezondheid".

Dalam Undang-undang Kesehatan ini, sebagai hasil konversi dari aturan-aturan belanda, nuansa hukum Islam yang sangat sedikit. Sebagaimana dua pasal yang disebutkan di atas. Aturan tersebut masih berkisar aturan-aturan hukum kesehatan secara umum. Karena undang-undang ini adalah hasil terjemahan dari aturan kesehatan yang ada di Belanda. Elemen Hukum Islam yang ditemukan di dalamnya hanyalah berkisar pengaturan minuman keras dan bimbingan beribadah bagi penderita. (pasal 11 dan pasal 8).

2. UU Nomor 23 terahun 1992

UU Tahun 1960 tersebut kemudian disempurnakan dengan Undang-Undang Republik Indonesia Nomor 23 Tahun 1992 Tentang Kesehatan yang berisi tentang 
aturan-aturan kesehatan yang menggabungkan aturan-aturan kesehatan yang telah ada sebelumnya. ${ }^{9}$

Dalam undang-undang ini menurut hemat penulis sudah mulai mengatur lebih luas tentang hukum Islam, karena sudah memuat aturan-aturan tentang Aborsi, Transpalansi organ tubuh/bedah plastik, Transfusi darah, bayi tabung, dan Zat Adiktif, namun belum mengatur tentang bayi tabung (kelahiran di luar rahim), dan donor darah. Di samping aturan-aturan lainnya yang berkaitan dengan pelaksanaan kesehatan. Hal ini sudah dicakup dalam UU berikutnya, yaitu :

3. UU Nomor 36 Tahun 2009

Setelah 17 Tahun Undang-Undang Nomor 23 Tahun 1992 tentang Kesehatan dilaksanakan dalam bidang kesehatan, Aturan tersebut dianggap sudah tidak sesuai lagi dengan perkembangan, tuntutan, dan kebutuhan hukum dalam masyarakat sehingga perlu dicabut dan diganti dengan Undang-Undang tentang Kesehatan yang baru yaitu Undang-undang nomor 36 tahun 2009; Undang-undang ini terdiri dari 205 Pasal dan 22 BAB. ${ }^{10}$

Dari gambaran yang diungkapkan ini dapat dijelaskan bahwa Undang-undang ini lebih rinci dan sudah lebih luas wewenangnya sesuai dengan perkembangan teknologi kesehatan dan informasi. Berikut ini hal-hal yang menjadi aturan-aturan kesehatan yang memiliki titik singgung dengan Hukum Islam.

Pasal-pasal tentang Zat Adiktif

Pasal 113

a. Pengamanan penggunaan bahan yang mengandung zat adiktif diarahkan agar tidak mengganggu dan membahayakan kesehatan perseorangan, keluarga, masyarakat, dan lingkungan.

b. Zat adiktif sebagaimana dimaksud pada ayat (1) meliputi tembakau, produk yang mengandung tembakau, padat, cairan, dan gas yang bersifat adiktif yang penggunaannya dapat menimbulkan kerugian bagi dirinya dan/atau masyarakat sekelilingnya.

c. Produksi, peredaran, dan penggunaan bahan yang mengandung zat adiktif harus memenuhi standar dan/atau persyaratan yang ditetapkan.

Pasal 114

Setiap orang yang memproduksi atau memasukkan rokok ke wilayah Indonesia wajib mencantumkan peringatan kesehatan.

${ }_{9}^{9}$ UU nomor 23 tahun 1992. Pasal 8. (www.Kemendagri.org.)

${ }^{10}$ UU nomor 36 tahun 2009. (www.Kemendagri.org.) 
142 Tazkir Vol. 01 No. 2 Juli - Desember 2015

Pasal 115

(1) Kawasan tanpa rokok antara lain:

a. fasilitas pelayanan kesehatan;

b. tempat proses belajar mengajar;

c. tempat anak bermain;

d. tempat ibadah;

e. angkutan umum;

f. tempat kerja; dan

g. tempat umum dan tempat lain yang ditetapkan.

(2) Pemerintah daerah wajib menetapkan kawasan tanpa rokok di wilayahnya. ${ }^{11}$

\section{Pasal-pasal tentang Transpalansi Organ Tubuh}

Pasal 64

(1) Penyembuhan penyakit dan pemulihan kesehatan dapat dilakukan melalui transplantasi organ dan/atau jaringan tubuh, implan obat dan/atau alat kesehatan, bedah plastik dan rekonstruksi, serta penggunaan sel punca.

(2) Transplantasi organ dan/atau jaringan tubuh sebagaimana dimaksud pada ayat (1) dilakukan hanya untuk tujuan kemanusiaan dan dilarang untuk dikomersialkan.

(3) Organ dan/atau jaringan tubuh dilarang diperjualbelikan dengan dalih apapun.

Pasal 65

(1) Transplantasi organ dan/atau jaringan tubuh hanya dapat dilakukan oleh tenaga kesehatan yang mempunyai keahlian dan kewenangan untuk itu dan dilakukan di fasilitas pelayanan kesehatan tertentu.

(2) Pengambilan organ dan/atau jaringan tubuh dari seorang donor harus memperhatikan kesehatan pendonor yang bersangkutan dan mendapat persetujuan pendonor dan/atau ahli waris atau keluarganya.

(3) Ketentuan mengenai syarat dan tata cara penyelenggaraan transplantasi organ dan/atau jaringan tubuh sebagaimana dimaksud pada ayat (1) dan ayat (2) ditetapkan dengan Peraturan Pemerintah.

Pasal 67

(1) Pengambilan dan pengiriman spesimen atau bagian organ tubuh hanya dapat dilakukan oleh tenaga kesehatan yang mempunyai keahlian dan kewenangan serta dilakukan di fasilitas pelayanan kesehatan tertentu. 
(2) Ketentuan mengenai syarat dan tata cara pengambilan dan pengiriman spesimen atau bagian organ tubuh sebagaimana dimaksud pada ayat (1) dilaksanakan sesuai dengan ketentuan peraturan perundangundangan.

Pasal 68

(1) Pemasangan implan obat dan/atau alat kesehatan ke dalam tubuh manusia hanya dapat dilakukan oleh tenaga kesehatan yang mempunyai keahlian dan kewenangan serta dilakukan di fasilitas pelayanan kesehatan tertentu.

(2) Ketentuan mengenai syarat dan tata cara penyelenggaraan pemasangan implan obat dan/atau alat kesehatan sebagaimana dimaksud pada ayat (1) ditetapkan dengan Peraturan Pemerintah.

Pasal 69

(1) Bedah plastik dan rekonstruksi hanya dapat dilakukan oleh tenaga kesehatan yang mempunyai keahlian dan kewenangan untuk itu.

(2) Bedah plastik dan rekonstruksi tidak boleh bertentangan dengan norma yang berlaku dalam masyarakat dan tidak ditujukan untuk mengubah identitas.

(3) Ketentuan mengenai syarat dan tata cara bedah plastic dan rekonstruksi sebagaimana dimaksud pada ayat (1) dan ayat (2) ditetapkan dengan Peraturan Pemerintah.

Pasal 70

(1) Penggunaan sel punca hanya dapat dilakukan untuk tujuan penyembuhan penyakit dan pemulihan kesehatan, serta dilarang digunakan untuk tujuan reproduksi.

(2) Sel punca sebagaimana dimaksud pada ayat (1) tidak boleh berasal dari sel punca embrionik.

(3) Ketentuan lebih lanjut mengenai penggunaan sel punca sebagaimana dimaksud pada ayat (1) dan ayat (2) diatur dengan Peraturan Menteri. ${ }^{12}$

\section{Pasal-pasal tentang Aborsi}

Pasal 75

(1) Setiap orang dilarang melakukan aborsi.

(2) Larangan sebagaimana dimaksud pada ayat (1) dapat dikecualikan berdasarkan:

a. Indikasi kedaruratan medis yang dideteksi sejak usia dini kehamilan, baik yang mengancam nyawa ibu dan/atau janin, yang menderita penyakit genetik 
berat dan/atau cacat bawaan, maupun yang tidak dapat diperbaiki sehingga menyulitkan bayi tersebut hidup di luar kandungan; atau

b. Kehamilan akibat perkosaan yang dapat menyebabkan trauma psikologis bagi korban perkosaan.

(3) Tindakan sebagaimana dimaksud pada ayat (2) hanya dapat dilakukan setelah melalui konseling dan/atau penasehatan pra tindakan dan diakhiri dengan konseling pasca tindakan yang dilakukan oleh konselor yang kompeten dan berwenang.

(4) Ketentuan lebih lanjut mengenai indikasi kedaruratan medis dan perkosaan, sebagaimana dimaksud pada ayat (2) dan ayat (3) diatur dengan Peraturan Pemerintah.

Pasal 76

Aborsi sebagaimana dimaksud dalam Pasal 75 hanya dapat dilakukan:

a. sebelum kehamilan berumur 6 (enam) minggu dihitung dari hari pertama haid terakhir, kecuali dalam hal kedaruratan medis;

b. oleh tenaga kesehatan yang memiliki keterampilan dan kewenangan yang memiliki sertifikat yang ditetapkan oleh menteri;

c. dengan persetujuan ibu hamil yang bersangkutan;

d. dengan izin suami, kecuali korban perkosaan; dan

e. penyedia layanan kesehatan yang memenuhi syarat yang ditetapkan oleh Menteri.

Pasal 77

Pemerintah wajib melindungi dan mencegah perempuan dari aborsi sebagaimana dimaksud dalam Pasal 75 ayat (2) dan ayat (3) yang tidak bermutu, tidak aman, dan tidak bertanggung jawab serta bertentangan dengan norma agama dan ketentuan peraturan perundang-undangan. ${ }^{13}$

Pasal-pasal tentang Keluarga Berencana (vasektomi/tubektomi) Pasal 78

(1) Pelayanan kesehatan dalam keluarga berencana dimaksudkan untuk pengaturan kehamilan bagi pasangan usia subur untuk membentuk generasi penerus yang sehat dan cerdas. 
(2) Pemerintah bertanggung jawab dan menjamin ketersediaan tenaga, fasilitas pelayanan, alat dan obat dalam memberikan pelayanan keluarga berencana yang aman, bermutu, dan terjangkau oleh masyarakat.

(3) Ketentuan mengenai pelayanan keluarga berencana dilaksanakan sesuai dengan peraturan perundangundangan.

Pasal-pasal tentang Bedah Mayat

Pasal 117

Seseorang dinyatakan mati apabila fungsi sistem jantung sirkulasi dan sistem pernafasan terbukti telah berhenti secara permanen, atau apabila kematian batang otak telah dapat dibuktikan.

Pasal 123

(1) Pada tubuh yang telah terbukti mati batang otak dapat dilakukan tindakan pemanfaatan organ sebagai donor untuk kepentingan transplantasi organ.

(2) Tindakan pemanfaatan organ donor sebagaimana dimaksud pada ayat (1) harus memenuhi ketentuan peraturan perundang-undangan. ${ }^{14}$

\section{Pasal tentang Bayi Tabung}

Pasal 127

(1) Upaya kehamilan di luar cara alamiah hanya dapat dilakukan oleh pasangan suami istri yang sah dengan ketentuan:

a. hasil pembuahan sperma dan ovum dari suami istri yang bersangkutan ditanamkan dalam rahim istri dari mana ovum berasal;

b. dilakukan oleh tenaga kesehatan yang mempunyai keahlian dan kewenangan untuk itu; dan

c. pada fasilitas pelayanan kesehatan tertentu.

(2) Ketentuan mengenai persyaratan kehamilan di luar cara alamiah sebagaimana dimaksud pada ayat (1) diatur dengan Peraturan Pemerintah. ${ }^{15}$

Setelah mengemukakan pasal-pasal terkait dengan hukum Islam, selanjutnya akan kemiripan dari pasal tersebut dengan hukum Islam.

Pandangan Islam terhadap tindakan aborsi karena perkosaan dapat dilihat berdasarkan pandangan dan pendapat para ulama ke empat madzhab yakni Maliki, Hambali, Hanafi dan Syafi'i yang secara umum menyetujui tindakan aborsi 
sebelum usia janin 40 hari. ${ }^{16}$ Sementara fatwa MUI tahun 2005 menyetujui secara tegas tindakan aborsi karena perkosaan dengan persyaratan usia janin tidak lebih dari 40 hari, kondisi ibu hamil terganggu secara mental, dilakukan di sarana kesehatan/rumah sakit tertentu dan diputuskan oleh sebuah tim yang terdiri dari ahli kesehatan, tokoh masyarakat dan ulama begitu juga.

Legalisasi tindakan aborsi karena perkosaan seperti yang diatur dalam Pasal 75 UU Kesehatan secara prinsip merupakan upaya perlindungan dan pemenuhan hak asasi perempuan terutama hak reproduksi dan hak hidup serta mempertahankan kehidupan. Sebelum UU ini, yakni UU No. 23 Tahun 1992 tentang Kesehatan telah memberikan pengecualian terhadap tindakan aborsi tersebut yakni meniadakan unsure kesalahan dalam perbuatan tersebut dengan alasan adanya indikasi medis.

Dalam Pasal 15 UU NO No. 23 Tahun 1992 ditekankan bahwa penghentian kehamilan dapat dilakukan apabila berdasarkan indikasi medis dimana kehamilan itu akan membahayakan nyawa ibu dan/atau janin.

Surjono Ekotomo memberikan pengertian terhadap abortus provocatus sebagai sebuah tindakan yang menghentikan kehamilan dengan cara disengaja sebelum usia kehamilan 20 minggu. Konsep ini mengacu pada istilah dari segi medis yang memberikan batasan usia 20 minggu untuk suatu keluarnya hasil konsepsi (pembuahan) dengan berat mudigah kurang dari 500 gram yang dapat disebut sebagai aborsi. Karena apabila sesudah usia $20 \mathrm{minggu}$ disebut dengan istilah partum (persalinan) dengan peluang hidup janin lebih besar dibanding usia sebelum 20 minggu. ${ }^{17}$

Bila dilihat dari Pasal 345 dan 346 KUHP tindakan pengguguran kandungan merupakan suatu tindak pidana, dengan atau tanpa persetujuan perempuan yang mengandung. Bahkan bagi orang lain yang menganjurkan tindakan ini saja sudah diancam sanksi pidana. Hal ini menunjukkan bahwa segala hal yang berhubungan dengan tindakan aborsi adalah sebuah tindak pidana. Dalam Kitab Undang-Undang Hukum Pidana Masalah abortus provocatus diatur dalam beberapa pasal antara lain:

a. Pasal 299 (1)

Barangsiapa dengan sengaja mengobati seorang wanita atau menyuruhnya supaya diobati, dengan sengaja memberitahukan atau ditimbulkan harapan,

16 'Abd al-Qadir 'Audah, al-Tasyri' al-Janaiy al-Islamy, (Beirut:Muassasah al-Risalah, 1992), hal. 292-293.

17 Suryono Ekotomo, Abortus Provocatus Bagi Korban Perkosaan, Perspektif Viktimologi, Kriminologi dan Hukum Pidana;( Yogyakarta: Penerbit Universitas Atma Jaya, 2001), hal. 25-26 
bahwa karena pengobatan itu hamilnya dapat digugurkan, diancam pidana penjara paling lama empat tahun. ${ }^{18}$

b. Pasal 346 :

Seorang wanita yang sengaja menggugurkan atau mematikan kandungannya atau menyuruh orang lain untuk itu, diancam dengan pidana penjara paling lama empat tahun.

c. Pasal 347

(1) Barangsiapa dengan sengaja menggugurkan atau mematikan kandungan seorang wanita tanpa persetujuannya diancam dengan pidana penjara paling lama dua belas tahun.

d. Pasal 348

(1) Barangsiapa dengan sengaja mengugurkan atau mematikan kandungan seorang wanita dengan persetujuannya diancam dengan pidana penjara paling lama lima tahun enam bulan. ${ }^{19}$

Prinsip ini kemudian diperkuat oleh ketentuan di dalam Pasal 75 ayat (1) UU Kesehatan.

Aborsi yang ada dalam UU Kesehatan merupakan pengecualian dari ketentuan yang terdapat dalam KUHP yang telah diuraikan di atas. Pengaturan tentang penghentian kehamilan atau aborsi termasuk dalam bab tentang Kesehatan Reproduksi dan masalah aborsi diatur dalam Pasal 75 sampai dengan Pasal 79.

Pengertian aborsi dalam fiqh berasal dari bahasa Arab Al-ijhadh, merupakan mashdar dari ajhadha atau juga dalam istilah lain bisa disebut dengan isqath alhaml, keduanya mempunyai arti perempuan yang melahirkan secara paksa dalam keadaan belum sempurna penciptaannya. ${ }^{20}$

Secara bahasa disebut juga lahirnya janin karena dipaksa atau dengan sendirinya sebelum waktunya. Sedangkan makna gugurnya kandungan menurut ahli fiqh tidak keluar dari makna bahasa, diungkapkan dengan istilah menjatuhkan (isqath), membuang (tharh), melempar (ilqaa') dan melahirkan dalam keadaan mati (imlaash.). ${ }^{21}$

\footnotetext{
${ }^{18}$ KUHP dan KUHAP, (Bandung: Citra Umbara, 2010, cet ke VI), hal. 95

${ }^{19}$ Ibid., hal. 108-109.

20 'Audah, loc., Cit. Juga Maria Ulfah Anshor; ; Fiqih Aborsi, Wacana Penguatan Hak Reproduksi Perempuan; (Jakarta: Penerbit Buku Kompas, 2006), hal. 31-32

${ }^{21} \mathrm{Ibid}$.
} 
Berkaitan dengan pendapat para Fuqaha, pendapat para ulama sangat beragam, meskipun dengan argumentasi yang sama-sama bersumber pada teks.Ulama dari Madzhab Hanafi membolehkan pengguguran kandungan sebelum kehamilan berusia 120 hari dengan alasan belum terjadi penciptaan. Pandangan sebagian ulama lain dari madzhab ini hanya membolehkan sebelum kehamilan berusia 80 hari dengan alasan penciptaan terjadi setelah memasuki masa mudghah atau janin memasuki usia 40 hari kedua. ${ }^{22}$

Sementara mayoritas ulama Hanabilah membolehkan pengguguran kandungan selama janin masih dalam bentuk segumpal darah ('alaqah) karena belum berbentuk manusia. Syafi'iyah melarang aborsi dengan alasan kehidupan dimulai sejak konsepsi sebagaimana dikemukakan oleh Al-Ghazali dalam Ihya Ulunuddin, tetapi sebagian lain dari mereka yaitu Abi Sad dan Al-Qurthubi membolehkan. Namun Al-Ghazali dalam Al-Wajiz pendapatnya berbeda dengan Al-Ihya, dimana beliau mengakui kebenaran pendapat bahwa aborsi dalam bentuk segumpal darah atau segumpal daging tidak apa-apa karena belum terjadi penyawaan. ${ }^{23}$

Munas Ulama Nahdatul Ulama (NU) tahun 2002 telah memberikan wacana fiqh aborsi bahwa aborsi dilarang karena merupakan pembunuhan terhadap calon manusia, kecuali untuk menyelamatkan nyawa ibu. Begitu pula keputusan Majelis Tarjih Muhammadiyah pada Muktamar Tarjih ke XXII di Malang menyebutkan aborsi dilarang karena merupakan perbuatan yang menentang harkat dan martabat manusia. ${ }^{24}$

Sementara Majelis Ulama Indonesia (MUI), yang menjadi "kiblat" pemerintah untuk mengeluarkan kebijakan terkait masalah-masalah keIslaman, pada tahun 1983 MUI Mengeluarkan Fatwa tentang kependudukan, kesehatan dan pembangunan, yang salah satu keputusannya menyatakan tentang aborsi, yang berbunyi bahwa "Pengguguran kandungan (abortus) termasuk MR (Menstrual Regulation) dengan cara apapun dilarang oleh jiwa dan ajaran Islam (haram) baik dikala janin sudah bernyawa (Umura 4 Bulan dalam Kandungan) ataupun dikala janin belum bernyawa (belum berumur 4 Bulan dalam Kandungan) karena perbuatan itu merupakan pembunuhan terselubung yang dilarang oleh syariat Islam, kecuali untuk menyelamatkan jiwa si ibu". ${ }^{25}$

22 'Audah,op.cit., hal. 295-296

23 'Audah., ibid., hal. 297

${ }^{24}$ Maria Ulfah, op.cit., hal. 35.

25 MUI, ibid., hal. 327. Fatwa tentang Kependudukan,Kesehatan dan Pembangunan. Fatwa ini dikeluarkan tanggal 3 Desember 1983. 
Pada tahun $2000^{26}$ MUI mengeluarkan fatwa yang khusus berkenaan dengan Aborsi yang keputusannya mengukuhkan fatwa tahun 1983 tersebut di atas, kemudian ditambah dengan pernyataan : "Mengharamkan semua pihak untuk melakukan, membantu, atau mengizinkan aborsi".

Kemudian pada tahun 2005 Komisi Fatwa Majelis Ulama Indonesia (MUI) menetapkan fatwa nomor 4 Tahun 2005 tentang Aborsi. Fatwa ini juga menghasilkan keputusan tentang keharaman melakukan aborsi dengan menyatakan " Aborsi haram hukumnya sejak terjadinya implantasi pada dinding rahim ibu (nidasi)".

Namun dalam Fatwa ini juga memutuskan bahwa aborsi dibolehkan karena ada uzur, baik bersifat darurat ataupun hajat, yaitu pada keadaan :

a. Perempuan hamil menderita sakit fisik berat seperti kanker stadium lanjut.

b. Dalam keadaan dimana kehamilan mengancam nyawa si ibu.

c. Janin yang dikandung dideteksi menderita cacat genetic yang kalau lahir sulit disembuhkan.

d. Kehamilan akibat perkosaan yang ditetapkan oleh tim yang berwenang.

Namun kebolehan ini harus dilakukan sebelum janin berusia 40 hari.berbeda yang menyangkut masalah aborsi.

Dari Fatwa ini dapat dijelaskan bahwa aborsi bisa dilakukan bila kehamilan disebabkan oleh kasus pemerkosaan dan inses (hubungan sedarah). Dan, syaratnya, aborsi hanya diizinkan bila usia janin dalam kandungan belum mencapai 40 hari. Selain itu, dikeluarkan fatwa boleh menggugurkan janin, bila secara genetis janin yang dikandung kelak akan menjadi masalah di kemudian hari, dengan usia janin tak lebih dari 40 hari. Ini terbilang mengejutkan, mengingat selama ini MUI menutup pintu rapat-rapat pada berbagai kemungkinan aborsi.

Jika kita bandingkan dengan bunyi pasal 75 dan 76 UU nomor 36 Tahun 2009 tentang kesehatan yang menyatakan :

(1) Setiap orang dilarang melakukan aborsi.

(2) Larangan sebagaimana dimaksud pada ayat (1) dapat dikecualikan berdasarkan:

a. indikasi kedaruratan medis yang dideteksi sejak usia dini kehamilan, baik yang mengancam nyawa ibu dan/atau janin, yang menderita penyakit genetik berat dan/atau cacat bawaan, maupun yang tidak dapat diperbaiki sehingga menyulitkan bayi tersebut hidup di luar kandungan; atau

b. kehamilan akibat perkosaan yang dapat menyebabkan trauma psikologis bagi korban perkosaan.

${ }^{26}$ Majelis Ulama Indonesia, Kumpulan Fatwa MUI sejak 1975, (Jakarta: Penerbit Erlangga, 2011), hal. 
(3) Tindakan sebagaimana dimaksud pada ayat (2) hanya dapat dilakukan setelah melalui konseling dan/atau penasehatan pra tindakan dan diakhiri dengan konseling pasca tindakan yang dilakukan oleh konselor yang kompeten dan berwenang.

(4) Ketentuan lebih lanjut mengenai indikasi kedaruratan medis dan perkosaan, sebagaimana dimaksud pada ayat (2) dan ayat (3) diatur dengan Peraturan Pemerintah.

\section{Pasal 76}

Aborsi sebagaimana dimaksud dalam Pasal 75 hanya dapat dilakukan:

a. sebelum kehamilan berumur 6 (enam) minggu dihitung dari hari pertama haid terakhir, kecuali dalam hal kedaruratan medis;

b. oleh tenaga kesehatan yang memiliki keterampilan dan kewenangan yang memiliki sertifikat yang ditetapkan oleh menteri;

c. dengan persetujuan ibu hamil yang bersangkutan;

d. dengan izin suami, kecuali korban perkosaan; dan

e. penyedia layanan kesehatan yang memenuhi syarat yang ditetapkan oleh Menteri.

Penulis menemukan ada kemiripan aturan tentang Aborsi, yaitu :

Kedua aturan tersebut menjelaskan larangan melakukan aborsi kecuali ditemukan ada indikasi kedaruratan (kata Darurat ini menjadi kata yang sama-sama dipakai dalam bunyi ketetapannya) medis yang dideteksi sejak dini (Kalimat ini persis apa yang ada dalam Fatwa MUI) kehamilan, baik yang mengancam nyawa si Ibu dan/ataujanin, yang menderita penyakit genetic berat dan/atau cacat bawaan, serta kebolehan melakukan aborsi pada kehamilan akibat perkosaan, dan tindakan tersebut dilakukan oleh tim yang berwenang.

Namun ada sedikit perbedaan terlihat pada usia janin dalam hal kebolehan melakukan aborsi, akan tetapi jika diperhitungkan hakikatnya sama, MUI memberi batasan usia janin sebelum janin berusia 40 hari, sementara Undang-undang Kesehatan menetapkan sebelum berumur 6 Minggu artinya kurang lebih 40-42 Hari.

Dari keterangan ini memungkinkan bahwa ketetapan tentang Aborsi dalam UU no 36 Tahun 2009 tersebut diyakini telah lebih dulu mempertimbangkan Fatwa MUI yang berkaitan dengan hal tersebut.

Fatwa MUI mengenai aborsi sudah tiga kali dikeluarkan. Fatwa yang satu menyempurnakan atau menjelaskan fatwa yang lainnya. Fatwa aborsi yang pertama dikeluarkan pada tanggal 28 Oktober 1983. Ketika itu MUI menyelenggarakan Musyawarah Nasional (Munas) Ulama khusus membahas masalah-masalah kependudukan (demographic issues), kesehatan (health), dan pembangunan 
(development). Salah satu bahagian dari keputusan Musyawarah itu mengenai kesehatan ialah mengenai keluarga berencana (family planning) yang antara lain mengatakan bahwa penggunaan alat kontrasepsi dalam rahim atau Internal Utarine Devices (IUD) dapat dibenarkan jika pemasangan dan pengontrolannya dilakukan oleh tenaga medis atau paramedis wanita atau bila terpaksa dapat dilakukan oleh tenaga medis pria dengan didampingi oleh suami atau wanita lain, sedangkan family planning dengan vasektomi dan tubektomi adalah haram hukumnya. Haram pula hukumnya melakukan pengguguran kandungan atau aborsi dengan cara apaun, termasuk MR (menstrual regulation), baik dikala bayi sudah bernyawa ataupun belum bernyawa, karena perbuatan itu merupakan pembunuhan manusia secara terselubung kecuali dimaksudkan untuk menyelamatkan nyawa si ibu. Banyak ayat Al-Quran dan hadis Nabi Muhammad telah dikutip sebagai landasan bagi fatwa itu, tetapi isinya bersifat umum saja karena tema Munas itu memang amat luas yaitu tentang kependudukan, kesehatan, dan pembangunan. ${ }^{27}$

Fatwa aborsi yang kedua dikeluarkan pada tanggal 29 Juli 2000, diputuskan dalam Musyawarah Nasional (Munas) MUI keenam tahun 2000. Fatwa itu dikeluarkan dengan alasan karena di tengah-tengah masyarakat muncul pro dan kontra mengenai hukum melakukan aborsi sebelum peniupan ruh (nafkh al-ruh). Fatwa itu mengatakan mengukuhkan keputusan Munas Ulama Indonesia tanggal 28 Oktober tahun 1983 dan menegaskan lagi bahwa melakukan aborsi sesudah nafkh al-ruh hukumnya ialah haram, kecuali apabila ada alasan medis seperti untuk menyelamatkan nyawa si ibu. Fatwa itu selanjutnya mengatakan bahwa melakukan aborsi sejak terjadinya pembuahan ovum, walaupun sebelum nafkh al-ruh, adalah juga haram, terkecuali ada alasan medis atau alasan lain yang dibenarkan oleh Syariat Islam. Fatwa itu juga mengharamkan semua pihak yang terlibat untuk melakukan, membantu, atau mengizinkan aborsi. ${ }^{28}$

Fatwa aborsi kedua ini mengutip beberapa ayat Al-Quran yang menerangkan mengenai proses dan tahapan-tahapan penciptaan manusia yaitu Surat Al-Mukminun ayat 12-14, Surat Al-Hajj ayat 5, dan Surat Al-Isra ayat 33). Fatwa itu juga mengutip hadis-hadis Nabi Muhammad SAW yang diriwayatkan oleh Imam Bukhari dan Imam Muslim yang menerangkan tentang waktu peniupan ruh (nafkh al-ruh) bagi si janin. Kemudian fatwa itu mengutip pendapat ulama yang bermacam-macam mengenai hukum aborsi sebelum nafkh al-ruh, ada yang membolehkannya secara mutlak, ada yang membolehkannya karena ada alasan medis (uzur), ada yang mengatakan makruh, dan ada pula yang mengatakan haram secara mutlak. Fatwa itu pun 
mengutip pendapat Imam Al-Ghazali bahwa jika sperma (nuthfah) telah bercampur (ikhtilat) dengan ovum dan siap menerima kehidupan (ist'idad li qabul al-hayah), maka merusaknya adalah haram hukumnya dan merupakan tindakan pidana. Akhirnya fatwa itu mengutip dua kaidah fiqhiyah, kesatu yang mengatakan: "Menghindarkan kerusakan diutamakan daripada mendatangkan kemaslahatan," dan kedua yang mengatakan: "Keadaan darurat membolehkan hal-hal yang dilarang."

Adapun fatwa aborsi yang ketiga dikeluarkan pada tanggal 21 Mei 2005, dengan alasan karena di dalam masyarakat ketika itu semakin banyak orang melakukan aborsi tanpa mengikuti tuntutan agama dan dilakukan oleh orang yang tidak memiliki kompetensi sehingga dapat membahayakan ibu yang mengandungnya dan masyarakat secara umum. Fatwa itu mengatakan bahwa aborsi haram hukumnya semenjak terjadinya implantasi blastosis pada dinding rahim ibu (nidasi). Aborsi hanya dibolehkan karena uzur, baik uzur yang bersifat darurat ataupun uzur hajat. Uzur yang bersifat darurat yaitu apabila perempuan yang hamil menderita sakit fisik berat seperti kanker stadium lanjut, TBC dengan caverna, dan penyakit-penyakit fisik berat lainnya yang ditetapkan oleh Tim dokter, atau kehamilan itu mengancam nyawa si ibu. Adapun uzur hajat yaitu apabila janin yang dikandung dideteksi menderita cacat genetic yang kalau lahir kelak sulit disembuhkan, atau kehamilan akibat perkosaan yang ditetapkan oleh tim yang berwenang yang di dalamnya antara lain terdapat keluarga korban, dokter, dan ulama. Fatwa itu menegaskan kebolehan semua aborsi yang dikecualikan itu hanya untuk dilakukan sebelum janin berusia 40 hari. Fatwa itu juga menegaskan bahwa aborsi haram hukumnya bagi kehamilan yang terjadi akibat perbuatan zina. ${ }^{29}$

Fatwa aborsi ketiga ini mengutip beberapa ayat Al-Quran tentang larangan membunuh anak karena takut kemiskinan (QS Al-An'am ayat 151 dan Isra'ayat 13) dan ayatayat Al-Quran mengenai tahapan penciptaan manusia (QS Al-Hajj ayat 5 dan Al-Mukminun ayat 12-14). Fatwa itu juga mengutipkan hadis-hadis Nabi Muhammad SAW tentang proses penciptaan manusia dalam perut ibunya dan saat ditiupkan ruh kepada janin. Dikutipkan juga hadis mengenai diat janin atas pembunuhan wanita yang sedang hamil. Setelah itu dikutipkan empat buah kaidah fiqhiyah yang masing-masingnya mengatakan: "Tidak boleh membahayakan diri sendiri dan tidak boleh pula membahayakan orang lain"; "Menghindarkan kerusakan diutamakan daripada mendatangkan kemaslahatan;" "Keadaan darurat membolehkan hal-hal yang dilarang;" dan "Hajat terkadang menduduki keadaan darurat." Pada bagian akhir uraian mengenai landasan fatwa kemudian dikutipkan bahwa ulama sepakat haram hukumnya bila aborsi dilakukan setelah nafkh al-ruh, tetapi 
ulama berbeda pendapat apabila aborsi dilakukan sebelum nafkh al-ruh. Dikutipkan pula pendapat Syaikh Atiyyah Shaqr, Ketua Komisi Fatwa Al-Azhar, yang mengatakan bahwa kehamilan karena zina tidak boleh digugurkan kandungannya, tetapi kehamilan karena diperkosa boleh digugurkan kandungannya.

Sungguh sangat menarik untuk memperhatikan fatwa MUI mengenai aborsi itu. Pertama, fatwa itu dikeluarkan berulang-ulang karena katanya semakin banyak orang melakukan aborsi tanpa mengikuti aturan agama Islam. Kedua, dari segi dalil yang dikemukakan selalu mengulang dalil-dalil dalam fatwa lama seraya menambahkan dalildalil baru baik berupa ayat Al-Quran, hadis Nabi, pendapat ulama, maupun kaedah-kaedah hukum yang digunakan. Fatwa kedua lebih lengkap dan lebih kuat dalilnya daripada fatwa pertama dan fatwa ketiga lebih lengkap dan lebih kuat dalilnya daripada fatwa kedua. Ketiga, dari segi aborsi yang boleh dilakukan selalu terjadi perluasan dan penambahan. Aborsi sesudah nafkh al-ruh semua ulama sepakat mengharamkannya, kecuali apabila kehamilan itu membahayakan nyawa si ibu. Hal itu dikatakan oleh fatwa pertama, kedua dan ketiga.

Dalam UU Kesehatan Republik Indonesia Nomor 36 Tahun 2009 terdapat beberapa pasal yang mengatur masalah-masalah bioetika yang telah dikeluarkan fatwanya oleh MUI. Pasal 64 ayat (1), (2), dan (3) dan Pasal 65 ayat (1) dan (2) UU itu mengatur mengenai transplantasi. Pasal-pasal itu mengatakan bahwa penyembuhan penyakit dan pemulihan kesehatan dapat dilakukan melalui transplantasi organ dan/atau jaringan tubuh, implant obat dan/atau alat kesehatan, bedah plastic dan rekonstruksi, serta penggunaan sel punca.

Transplantasi organ dan/atau jaringan tubuh itu dilakukan hanya untuk tujuan kemanusiaan dan dilarang untuk dikomersialkan. Organ dan/atau jaringan tubuh dilarang diperjualbelikan dengan dalih apapun juga. Transplantasi organ dan/atau jaringan tubuh hanya dapat dilakukan oleh tenaga kesehatan yang mempunyai keahlian dan kewenangan untuk itu dan dilakukan di tempat pelayanan kesehatan tertentu.

Pengambilan organ dan/atau jaringan tubuh dari seorang donor harus (wajib) memperhatikan kesehatan pendonor yang bersangkutan dan mendapat persetujuan pendonor dan/atau ahli waris keluarganya. Demikianlah pokok-pokok isi kedua pasal itu. Jelas sekali di situ diatur bahwa untuk pengambilan organ dan/atau jaringan tubuh itu harus mendapat persetujuan pendonor dan/atau ahli waris keluarganya sebagaimana juga dinyatakan oleh fatwa MUI mengenai hukum transplantasi tersebut di atas. Perbedaan antara fatwa MUI dan UU itu ialah bahwa MUI hanya mengasumsikan si pendonor itu telah wafat, sedangkan UU itu nampaknya memungkinkan si pendonor itu masih hidup seperti tersirat dari kata-kata "harus memperhatikan kesehatan pendonor."

Kemudian dalam UU Nomor 36 Tahun 2009 Tentang Kesehatan aborsi diatur lagi yang isinya bahwa selain tetap melarang aborsi, tetapi juga memperkenalkan konsep 
pengecualian, sebagaimana termuat pada Pasal 75 dan 76. Pada Pasal 75 UU itu dikatakan bahwa setiap orang dilarang melakukan aborsi. Larangan itu dapat dikecualikan berdasarkan indikasi kedaruratan medis yang dideteksi sejak usia dini kehamilan, baik yang mengancam nyawa ibu dan/atau janin yang menderita penyakit genetic berat dan/atau cacat bawaan, maupun yang tidak dapat diperbaiki sehingga menyulitkan bayi tersebut hidup di luar kandungan; atau kehamilan akibat perkosaan yang dapat menyebabkan trauma psikologis bagi korban perkosaan.

Tindakan aborsi yang dikecualikan itu hanya dapat dilakukan setelah melalui konseling dan/atau penasehatan pra-tindakan dan diakhiri dengan konseling pasca tindakan yang dilakukan oleh konseler yang kompeten dan berwenang. Ketentuan lebih lanjut mengenai indikasi kedaruratan medis dan perkosaan itu akan diatur lebih lanjut dengan Peraturan Pemerintah. Kemudian pada Pasal 76 diberikan catatan bahwa aborsi-aborsi yang dikecualikan itu hanya dapat dilakukan sebelum kehamilan berumur enam minggu dihitung mulai dari hari pertama haid terakhir, kecuali dalam hal kedaruratan medis. Juga dipersyaratkan bahwa aborsi yang dikecualikan itu dilakukan oleh tenaga kesehatan yang memiliki ketrampilan dan kewenangan yang memiliki sertifikat yang sah, dengan persetujuan ibu hamil yang bersangkutan, dengan izin suaminya kecuali dalam hal korban perkosaan, dan di tempat penyedia layanan kesehatan yang memenuhi syarat yang ditetapkan.

Kalau kita perhatikan persamaan dan perbedaan antara fatwa MUI terakhir tentang aborsi tahun 2005 dan bunyi Pasal 75 dan 76 UU Nomor 36 Tahun 2009 Tentang Kesehatan tersebut ternyata hampir seluruh persyaratan bagi aborsi yang dikecualikan itu sama dengan apa yang telah difatwakan oleh MUI, sehingga dapat dikatakan bahwa bunyi Pasal 75 dan 76 itu memang dipengaruhi oleh fatwa MUI yang terbit lebih dahulu dari UU tersebut.

\section{BEDAH MAYAT (Otopsi)}

Dalam Fatwa MUI Nomor 6 Tahun 2009 menetapkan keputusan tentang otopsi jenazah, yaitu :

1. Bahwa pada dasarnya setiap jenazah harus dipenuhi hak-haknya, dihormati keberadaannya dan tidak boleh dirusak.

2. Otopsi Jenazah dibolehkan jika ada kebutuhan yang ditetapkan oleh pihak yang punya wewenang untuk itu.

3. Otopsi jenazah harus memenuhi ketentuan sebagai berikut:

a) Didasarkan kepada kebutuhan secara syar'i (seperti mengetahui penyebab kematian untuk penyelidikan hukum, atau pendidikan kedokteran), ditetapkan oleh seorang atau lembaga yang berwenang dan dilakukan oleh ahlinya. 
b) Otopsi merupakan jalan keluar satu-satunya dalam memnuhi tujuan sebagaimana maksud pada poin a).

c) Jenazah yang diotopsi harus segera dipenuhi hak-haknya, seperti dimandikan, dikafani, dishalatkan, dan dikuburkan.

d) Jenazah yang akan dijadikan objek otopsi harus memperoleh izin dari dirinya sewaktu hidup melalui wasiat, izin dari ahli waris, dan atau izin dari pemerintah sesuai dengan ketentuan perundang-undangan. ${ }^{30}$

Dari ketentuan-ketentuan yang telah diungkapkan di atas, tergambar bahwa ditemukan adanya ketentuan-ketentuan dalam pasal-pasal yang ada dalam peraturan perundang-undangan bidang Kesehatan yang mengadopsi dan mengakomodasi bahkan menjadikan hukum Islam sebagai sumber perundang-undangan tersebut, hal ini terlihat dari redaksi pasal-pasal yang ada yang memiliki redaksi yang sangat mirip dengan fatwa-fatwa MUI.

\section{SIMPULAN}

Dari hasil penelitian yang dilakukan dapatlah diambil simpulan bahwa hukum Islam sesungguhnya telah eksis dalam peraturan perundang-undangan bidang kesehatan. Hal ini terbukti banyaknya pasal-pasal yang terkait dengan hukum Islam, anatara lain pengaturan tentang tidak diperbolehkannya jual beli darah, larangan terhadap bedah mayat, larangan terhadap tndakan aborsi dan aturan-aturan yang terkait dengannya, serta pasal-pasal lainnya yang merupakan hasil kontribusi hukum Islam, yang bersumber dari fatwa-fatwa yang pernah dikeluarkan oleh Majelis Ulama Indonesia.

${ }^{30}$ MUI, hal. 546. Fatwa ini dikeluarkan tanggal 6 Juni 2009. 
156 Tazkir Vol. 01 No. 2 Juli - Desember 2015

\section{DAFTAR KEPUSTAKAAN}

'Abd al-Qadir 'Audah, al-Tasyri' al-Janaiy al-Islamy, Beirut:Muassasah al-Risalah, 1992.

Dahlan, M.U., Pengantar Hukum Kesehatan, Korpri Sub Unit Kanwil Depkes, Propiosi Jawa Timur, Surabaya. 1988.

Dede Rosyada, Hukum Islam dan Pranata Sosial, Jakarta: Raja Grafindo Persada.

Dede Rosyada, Hukum Islam dan Pranata Sosial, Jakarta: Raja Grafindo Persada.

Djamil, Fathurrahman, Dr., MA., Filsafat Hukum Islam, Jakarta: logos Wacana Ilmu, Cet. II,1999.

H. M. Ichwan Sam, et al, HIMPUNAN FATWA DEWAN SYARIAH NASIONAL INDONESIA, edisi revisi, diterbitkan atas kerjasama Dewan Syariah Nasional Majlis Ulama Indonesia dan Bank Indonesia, Jakarta, 2006.

Harun, Nasrun., Ushul Fiqh 1, ( Jakarta: PT.Logos Wacana Ilmu, Cet II, 1997.

Hasan. M. Ali, Masail Fiqhiyah Al-Haditsah, Jakarta: PT. Raja Grafindo Persada, 2000

Ibn Qudamah, Raudah al-Nazhir wa Junnat al-Manazhir, Beirut: Dar al-Kutub al-alamiyah, 1994, cet ke-2.

Jurnalis Uddin, et al, REINTERPRETASI HUKUM ISLAM TENTANG ABORSI, penerbit Universitas Yarsi, 2006.

K. H. Makruf Amin, et al, HIMPUNAN FATWA MUI SEJAK 1975.

Khallaf, Abd al-Wahab, Mashadir al-Tasyri' al-Islamy fima la Nash fih, Kuwait: Dar al-Qolam, 1972, cet ke-3.

KUHP dan KUHAP, Bandung: Citra Umbara, 2010, cet ke VI

Majelis Ulama Indonesia, Kumpulan Fatwa MUI sejak 1975, Jakarta: Penerbit Erlangga, 2011.

Manan, Abdul, Reformasi Hukum Islam di Indonesia, Jakarta: Rajawali Press, 2006.

Maria Ulfah Anshor; ; Fiqih Aborsi, Wacana Penguatan Hak Reproduksi Perempuan; Jakarta: Penerbit Buku Kompas, 2006.

Mas'ud, Muhammad Khalid, Filsafat Hukum Islam dan Perubahan Sosial, terjemahan oleh Yudian W. Asmin, Surabaya: Al Ikhlas, 1995. 
Masyfuk Zuhdi, Masail Fiqh 1, Jakarta : PT. Bina Aksara, 1993.

Mohamad Atho Mudzhar, Fatwa-Fatwa Majlis Ulama Indonesia; Sebuah Studi Tentang Pemikiran Hukum Islam Di Indonesia, 1975-1988, Penterbit IndonesianNetherlands Cooperation in Islamic Studies (INIS), Jakarta, 1993.

Musthofa Zaid, Dr. al-Maslahat fi Tasyri' al-Islami wa Najm al-din al-Thufi, Dar al-Fikr al-arabi, Cet ke-2, 1964.

Qardawi ,Yusuf, Halal Dan Haram Dalam Islam, Jakarta : PT. Bina Aksara, 1993

Shidik Safiudin, Hukum Islam Tentang Berbagai Persoalan Kontemporer, Jakarta: Intimedia, 2004.

Sya'ban Muhammad Ismail, Dr., al-Tasyri' al-Islamy, Mesir: Maktabah Nahdhah almisri, cet ke-2, 1985,

Syahrin Harahap, Metodologi Studi Tokoh, Jakarta: Istiqomah Mulya Press, 2006.

Syahrin Harahap, Metodologi Studi Tokoh, Jakarta: Istiqomah Mulya Press, 2006.

Syarifuddin, Amir, Prof.,Dr., Ushul Figh, Jakarta: Kencana, Cet ke-5, 2011, Jilid 2.

Syekh Muhammad al-Thahir bin 'Asyuro, Maqasid al-syariah al-Islamiyah, Yordania: Dar alNafais, Cet ke-2, 2001.

Timoty Linsey, Law and Society, NSW:The federation Press, 1999

UU nomor 36 tahun 2009. (www.Kemendagri.org.)

Zuhaili, Wahbah, Ushul Figh Islamy, Damaskus: Dar al Fikr, 1986, juz 2. 